\title{
Formation of Solution-derived Hydroxyapatite Coatings on Titanium Alloy in the Presence of Magnetron-sputtered Alumina Bond Coats
}

\author{
Anna Zykova ${ }^{1, *}$, Vladimir Safonov ${ }^{1}$, Anna Yanovska ${ }^{2,3}$, Leonid Sukhodub ${ }^{3}$, Renata Rogovskaya ${ }^{4}$, \\ Jerzy Smolik ${ }^{4}$ and Stas Yakovin ${ }^{5}$
}

\author{
${ }^{I}$ National Science Centre, Kharkov Institute of Physics and Technology, Kharkov, Ukraine \\ ${ }^{2}$ Institute of Applied Physics National Academy of Sciences of Ukraine, Sumy, Ukraine \\ ${ }^{3}$ Sumy State University, Medical Institute, Ministry of Education and Science, Sumy, Ukraine \\ ${ }^{4}$ Institute for Sustainable Technologies, National Research Institute, Radom, Poland \\ ${ }^{5}$ Department of Physical Technologies, Kharkov National University, Kharkov, Ukraine
}

\begin{abstract}
Hydroxyapatite $\left.\mathrm{Ca}_{10}\left(\mathrm{PO}_{4}\right)_{6} \mathrm{OH}\right)_{2}(\mathrm{HAp})$ and calcium phosphate ceramic materials and coatings are widely used in medicine and dentistry because of their ability to enhance the tissue response to implant surfaces and promote bone ingrowth and osseoconduction processes. The deposition conditions have a great influence on the structure and biofunctionality of calcium phosphate coatings. Corrosion processes and poor adhesion to substrate material reduce the lifetime of implants with calcium phosphate coatings. The research has focused on the development of advanced methods to deposit double-layered ceramic oxide/calcium phosphate coatings by a hybrid technique of magnetron sputtering and thermal methods. The thermal method can promote the crystallization and the formation of HAp coatings on titanium alloy Ti6Al4V substrates at low temperature, based on the principle that the solubility of HAp in aqueous solutions decreases with increasing substrate temperature. By this method, hydroxyapatite directly coated the substrate without precipitation in the initial solution. Using a thermal substrate method, calcium phosphate coatings were prepared at substrate temperatures of $100-105{ }^{\circ} \mathrm{C}$. The coated metallic implant surfaces with ceramic bond coats and calcium phosphate layers combine the excellent mechanical properties of metals with the chemical stability of ceramic materials. The corrosion test results show that the ceramic oxide (alumina) coatings and the double-layered alumina-calcium phosphate coatings improve the corrosion resistance compared with uncoated Ti6Al4V and single-layered Ti6Al4V/calcium phosphate substrates. In addition, the double-layered alumina/hydroxyapatite coatings demonstrate the best biocompatibility during in vitro tests.
\end{abstract}

Keywords: Alumina, biocompatibility, hydroxyapatite, magnetron sputtering, thermal method, potentiodynamic testing.

\section{INTRODUCTION}

In recent years, there was a huge development in biomaterials for repair and reconstruction of different defects of human bone. Metal prostheses with coatings deposited by various physical and chemical methods are widely used in medicine. Most promising are coatings with bioactive properties that have the tendency to be gradually resorbed in the human body and substituted by bone tissue. Calcium phosphate, in particular hydroxyapatite (HAp) films and coatings are of special interest due to their superior osseoconductivity. Hydroxyapatite-coated components of modern prosthetic implants show a great potential for application in orthopedic and dental areas [1,2]. A variety of techniques were developed to deposit calcium phosphate coatings on metal substrates, including thermal spraying

*Address correspondence to the author at the National Science Centre Kharkov Institute of Physics and Technology", Kharkov, Ukraine;

Tel/Fax: +38(057) 33539 05; Email: zykova.anya@ gmail.com
[3-5], electrophoretic deposition [6, 7], magnetron sputtering [8], sol-gel deposition [9], and biomimetic methods [10].The main research effort is focusing on developing low cost and low temperature processes. Some effective methods such as magnetron sputtering, dip coating, and electrophoretic deposition form dense and adherent but amorphous or low crystalline coatings. Among other techniques, plasma spraying is most popular due to its high deposition rate and productivity. Another popular method to deposit HAp coatings with fine crystalline structure, uniform coating composition, and thickness is synthesis from aqueous solutions at elevated temperature ('thermal' method) [11-14].

The major factors affecting the implant fixation and its long-term stability are coating biodegradation and bone ingrowth processes. Deposited coatings as usual present a mixture of crystalline stoichiometric hydroxyapatite and additional phases, such as oxyhydroxyapatite, calciumdeficient hydroxyapatite, calcium oxide, $\alpha$-and $\beta$-tricalcium phosphate, and tetracalcium phosphate. All these additional 
phases are much easier to dissolve than crystalline HAp. The major biomedical properties (such as bioactivity, bioresorbability, osteoconductivity and osteoinductivity) of the multiphasic and polyphasic compositions might be adjusted by changing the ratio among the calcium orthophosphate phases. A balance of more stable calcium phosphate phases and more soluble calcium orthophosphate phases determines the main idea of the multiphasic concept. In vivo bioresorbability of HAp can be adjusted through the phase composition. As-sprayed HAp coatings are not stable enough to be applied clinically. A post-depositional treatment is frequently used to transform these fast degradable phases into crystalline HAp.

Highly crystalline HAp coatings with homogeneous composition are preferable to prevent thickness reduction during in vivo dissolution [15-19]. However, the insufficient purity and uniformity of HAp coatings, their low crystallinity, and poor adhesion to the substrate material reduce the lifetime of implants coated with HAp. In addition, corrosion is one of the major processes that cause problems when metals and alloys are being used as implants in the body [20]. Corrosion of implants in the aqueous medium of body fluids takes place via electrochemical reactions [21]. The body fluid environment may well decrease the fatigue strength of the metal implant and enhance the release of iron, chromium, nickel, or titanium ions that are known to be powerful allergens and carcinogens. The presence of titanium compounds in the tissue surrounding these implants and subsequent failure of implants due to fatigue, stress corrosion cracking, and poor wear resistance have been reported [22, 23]. Release of metal ions into the tissues adjacent to the implants results in accumulation of harmful products in tissue and internal organs of living organisms $[24,25]$.

A major drawback of HAp coatings is that in some cases delamination of the coatings from the substrate material occurs due to poor bond strength and chemical stability. Titania and zirconia ceramic coatings were used as bond coats to improve the adhesion of HAp coatings to metal substrates [26-28]. Ceramic materials and coatings such as alumina $\left(\mathrm{Al}_{2} \mathrm{O}_{3}\right)$, partially stabilized zirconia (YSZ), and titania $\left(\mathrm{TiO}_{2}\right)$ possess high wear resistance, mechanical strength, and good biocompatibility [29-31]. The metallic implant surfaces coated with ceramic bond coats and hydroxyapatite layers combine the excellent mechanical properties of metals with chemical stability of ceramic materials and osseointegration ability of HAp.

The analyses of structure, composition, mechanical and corrosion properties, and biocompatibility of titanium alloys with single-layer HAp coatings and double-layered aluminum oxide/HAp coatings deposited by magnetron sputtering and thermal deposition methods are of great interest for biomedical application. In vitro tests of cytotoxicity and cell viability on materials and coated surfaces are the basic tools to determine the material surface/tissue response on a cellular level.

\section{MATERIALS AND METHODS}

The substrates for coating deposition consisted of standard titanium alloy (Ti6Al4V) ultrasonically cleaned in acetone, $96 \%$ ethanol, distilled water, and subsequently dried in a drying oven.

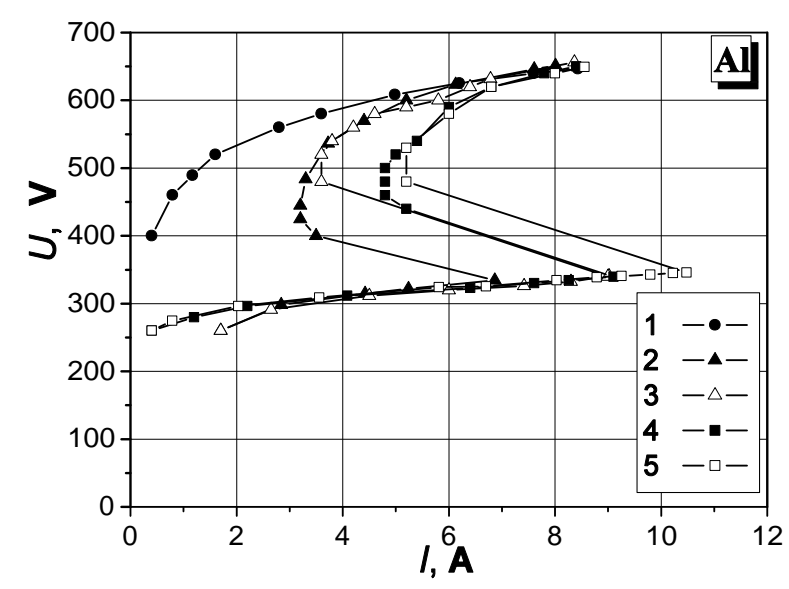

Fig. (1). Current-voltage characteristics of magnetron discharge in argon with oxygen for aluminum target material [31]. Ar pressure: $6 \times 10^{-2} \mathrm{~Pa}$. Oxygen flow: $1: \mathrm{q}=0 \mathrm{sccm}$ (standard cubic centimeter/minute), 2,3: $\mathrm{q}=17 \mathrm{sccm}, 4,5: \mathrm{q}=26 \mathrm{sccm}$.

Alumina coatings were deposited in a high vacuum pumping system with a base pressure of about $10^{-2} \mathrm{~Pa}$ by ion source-assisted magnetron sputtering. A pure aluminum target was used. The distance to substrate was about $30 \mathrm{~cm}$. Power to the sputtered cathode was applied using $10 \mathrm{~kW} \mathrm{DC}$ power supply operated either in current or voltage regulation mode. The magnetron system was equipped by a coil of the magnetic field, permanent magnet, RF generator and inductive coil. Argon was used as the sputtering gas. Oxygen for the reactive deposition was delivered through the ICP plasma source. Flows for both argon and oxygen were regulated using mass flow controllers operated by twochannel process control unit.The magnetron discharge power was between 1 and $4 \mathrm{~kW}$, the power of the activated oxygen source was up to $1 \mathrm{~kW}$, and the coating deposition rate was 8 $\mu \mathrm{m} /$ hour $[31,32]$.

The sputtering process was performed in a regime far from the target passivation mode to obtain ceramic coatings with oxide stoichiometric composition. In addition, such deposition conditions allow avoiding micro-arcing and micro-drop formation thus increasing the corrosion resistance properties. The optimum conditions were realized for the upper part of the current-voltage curves of magnetron discharge in argon with oxygen (Fig. 1).

The main feature of the thermal method used to form calcium phosphate and hydroxyapatite coatings is the thermal activation near the substrate immersed in aqueous solutions containing HAp-forming components. The solubility of HAp in aqueous solutions decreases with increasing temperature and the relationship between the solubility $\mathrm{Ks}\left(\mathrm{mol} \cdot \mathrm{dm}^{-3}\right)^{9}$ and temperature $\mathrm{T}(\mathrm{K})$ is given by the equation [33].

$\log \mathrm{Ks}=\log \left[\mathrm{Ca}^{2+}\right]^{5}\left[\mathrm{PO}_{4}^{3-}\right]^{3}\left[\mathrm{OH}^{-}\right]=-8219.41 / \mathrm{T}-1.6657-$ $0.098215 \mathrm{~T}$ 
The experimental set-up (Fig. 2) was previously described in detail in Ref. [34].

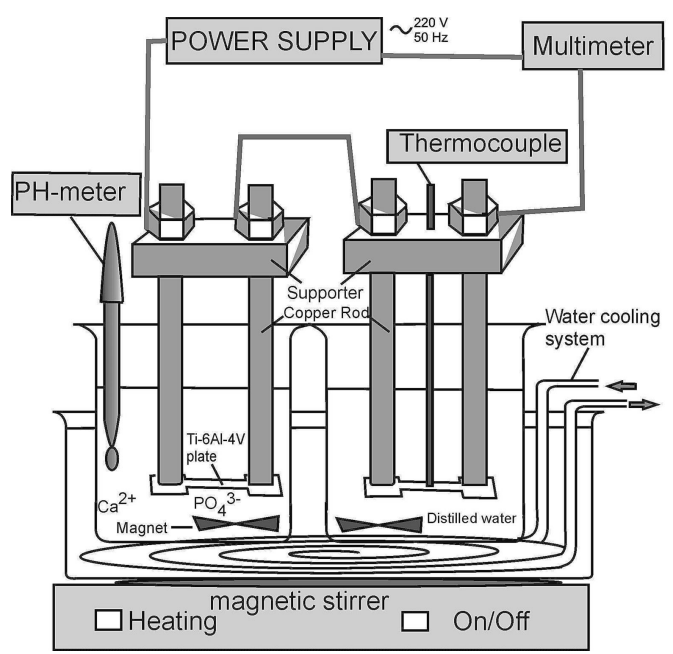

Fig. (2). The experimental setup used for producing calcium phosphate coatings by the thermal deposition method [34].

The HAp coatings were deposited on Ti6Al4V and Ti6Al4V/Al2O3 substrates by the thermal method from aqueous solution.

The substrates were fixed by copper electrodes and immersed in $6 \mathrm{mmol} / \mathrm{l} \mathrm{NaH}_{2} \mathrm{PO}_{4}$ and $10 \mathrm{mmol} / \mathrm{l} \mathrm{CaCl}_{2}$ solutions with a molar ratio $\mathrm{Ca} / \mathrm{P}=1.67$. The tested samples were heated to set-point temperature interval $\left(100-105^{\circ} \mathrm{C}\right)$ by variation of current values near $10 \mathrm{~A}$. A copper-constantan thermoelectric couple controlled the substrate temperature. A magnetic stirrer was used to maintain a uniform temperature distribution in the primary solution volume. The substrate temperature was around $100-105{ }^{\circ} \mathrm{C}$ and deposition lasted for 2 hours according to previous results of X-ray diffraction and X-ray microanalysis of uniform base phase formation with $\mathrm{Ca} / \mathrm{P}$ ratio close to that of hydroxyapatite [12]. The $\mathrm{pH}=6.5$ of the reactant solution was adjusted by adding sodium hydroxide.

The chemical reaction for HAp coatings formation is:

$5 \mathrm{CaCl}_{2}+3 \mathrm{NaH}_{2} \mathrm{PO}_{4}+7 \mathrm{NaOH} \rightarrow \mathrm{Ca}_{5}\left(\mathrm{PO}_{4}\right)_{3} \mathrm{OH}+10 \mathrm{NaCl}+$ $7 \mathrm{H}_{2} \mathrm{O}$

The surface morphology of coatings produced by magnetron sputtering surface pretreatment were examined by scanning electron microscopy (SEM). These investigations were carried out in combination with X-ray emission spectroscopy using the REMMA-102 device (SELMI, Ukraine). The surface chemical composition was determined with an energy-dispersive X-ray (JSC SELMI) Si(Li) detector equipped with a beryllium window. The power resolution of the energy-dispersive spectrometer (EDS) used was $200 \mathrm{eV}$, the probe current was about $3 \mathrm{nA}$, and the accelerating voltage of the electronic probe was $20 \mathrm{kV}$. The spectrum acquisition time at each point was about 200 seconds. The analytical signal of the characteristic X-ray emission was integrated by scanning a $50 \times 50 \mu \mathrm{m}^{2}$ area of the samples. SEM acquired micrographs of surfaces with single- and double-layered coatings with different magnifications in conjunction with EDS.
The adhesion, hardness and Young's elastic moduli of the coatings were measured by standard methods using a Revetest (CSM Instruments) with a Rockwell indenter with a tip radius $200 \mu \mathrm{m}$, within the load range of 200N[31]. Coating thicknesses were measured with a Calotest Calowear tester (CSM Instruments).

The corrosion parameters of single- and double-layered coatings were determined using a potentiostat Parstat 2263 (Ametek, USA). Anodic polarization was measured by a potentiodynamic method in the potential range between $1.0 \mathrm{~V}$ and $+2.0 \mathrm{~V}$ with a scanning rate of $1 \mathrm{mV} / \mathrm{s}$ in $\mathrm{SBF}$ solution. The composition of the $\mathrm{SBF}$ in $\mathrm{g} / \mathrm{l}$ was $\mathrm{NaCl} 8.035$, $\mathrm{NaHCO}_{3} \quad 0.355, \quad \mathrm{KCl} \quad 0.225, \quad \mathrm{~K}_{2} \mathrm{HPO}_{4} \cdot 3 \mathrm{H}_{2} \mathrm{O} \quad 0.231$, $\mathrm{MgCl}_{2} \cdot 6 \mathrm{H}_{2} \mathrm{O} 0.311, \mathrm{CaCl}_{2} 0.292, \mathrm{Na}_{2} \mathrm{SO}_{4} 0.072$, at $\mathrm{pH}=7.4$. and $37{ }^{\circ} \mathrm{C}$. The samples were immersed in the electrolyte and the potential was monitored as a function of time until it reached a stable value. Corrosion in the form of anodic dissolution occurs in case of the substrate as dissolution-like uniform removal process and in case of the ceramic coating as corrosive electrolyte pore penetration process.

Cell viability and cytotoxicity were estimated in vitro tests by standard protocols. The cell cytology, morphology, and vital activity were determined by optical microscopy on cultivated substrates after $24 \mathrm{~h}$, and 3 and 5 days cultivation. Rat hypodermic cellular tissue was extracted to obtain an initial fibroblast culture. The suspension of extracted cells was centrifuged at 750 r.p.m. for $15 \mathrm{~min}$. The cell density was $3 \times 10^{5}$ cells $/ \mathrm{ml}$. The seeded area was $0.5 \mathrm{~cm}^{2}$. The fibroblasts were cultivated as a monolayer in $3 \mathrm{ml}$ of Dulbecco Modified Eagle's Medium (DMEM, Sigma) at thermostat condition $\left(37^{\circ} \mathrm{C}\right)$ for 5 days. The cells were stained by hematoxylin and eosin for further characterization of structural organization of cultured cells on coated and uncoated substrates. Cell structure and morphology were analyzed by optical microscopy (Micros-50). The experiments were run in triplicate. Cell viability was tested on Ti6Al4V, Ti6Al4V/Al ${ }_{2} \mathrm{O}_{3}$, Ti6Al4V/HAp and Ti6Al4V/ $\mathrm{Al}_{2} \mathrm{O}_{3} / \mathrm{HAp}$ substrates.

Qualitative and quantitative analyses were made. The number of detached cells was determined by quantitative assessment. Statistical processing of experimental results using the software package with a preliminary estimation of the normal distribution was conducted. Statistically significant differences were determined at a significance level $\mathrm{P}<0.05$.

\section{RESULTS AND DISCUSSION}

Photoelectron spectroscopy and X-ray diffraction analyses of the structure and composition of $\mathrm{Al}_{2} \mathrm{O}_{3}$ oxide coatings deposited by ion source-activated magnetron sputtering were previously reported [35]. The coatings have a dense and uniform amorphous structure with strong stoichiometric oxide composition. SEM and EDS analyses of alumina coatings deposited on Ti6Al4V substrates are shown in Fig. (3).

Fig. (4) shows SEM micrographs of calcium phosphate coatings deposited by the thermal method on Ti6Al4V substrates. Fig. (5) presents EDS analysis data that 

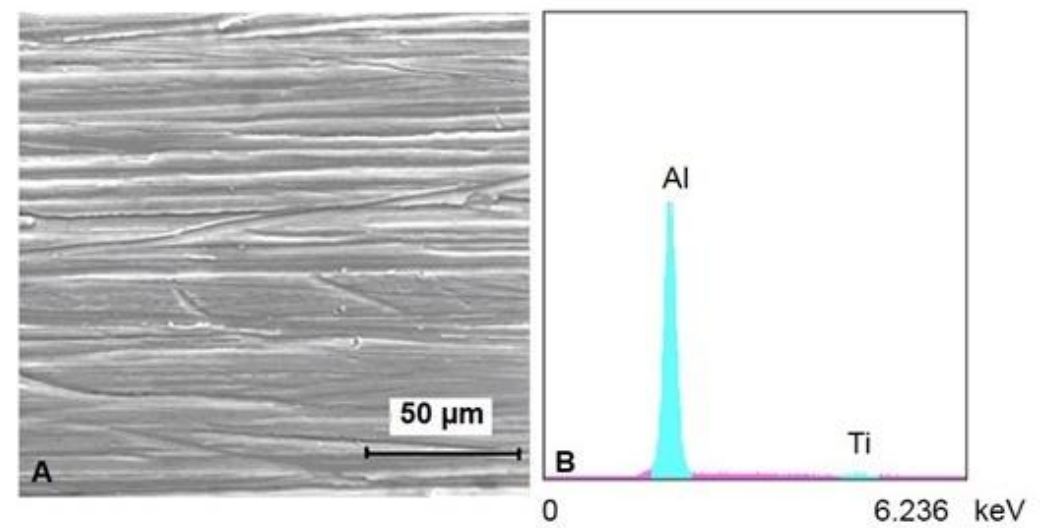

Fig. (3). (A) SEM micrograph of surface morphology of $\mathrm{Al}_{2} \mathrm{O}_{3}$ coatings deposited on a Ti6Al4Vsubstrate by magnetron sputtering. (B) EDS analysis results.

demonstrate the formation of calcium phosphate compounds. The results of the elemental analyses of selected points are shown in Table 1. The EDS data show a low $\mathrm{Ca} / \mathrm{P}$ ratio, which is result of calcium-deficient surface. An explanation of the deviation of the $\mathrm{Ca} / \mathrm{P}$ ratio from the stoichiometric value of hydroxyapatite may be found in the fact that formation of octacalcium phosphate $(\mathrm{OCP})$ with a $\mathrm{Ca} / \mathrm{P}$ ratio of 1.33 often occurs as a transient precursor/intermediate during precipitation of thermodynamically more stable HAp and biological apatites, as OCP nucleates and grows more easily than HAp. In addition, the surface layer may have a composition different from that of the bulk material. A difference in the surface and bulk stoichiometric ratios was also observed in Refs. [36, 37].

Table 1. Results of EDS elemental analysis of calcium phosphate crystalson a Ti6Al4V substrate at selected points shown in Fig. (5).

\begin{tabular}{|c|c|c|c|}
\hline Point & Ca & P & Ca/P ratio, at. \% \\
\hline \hline 1 & 21.07 & 11.62 & 1.41 \\
\hline 2 & 20.01 & 11.07 & 1.40 \\
\hline 3 & 20.96 & 12.57 & 1.29 \\
\hline
\end{tabular}

The results of the EDS analyses of calcium phosphate coatings deposited by the thermal method on Ti6Al4V/ $\mathrm{Al}_{2} \mathrm{O}_{3}$ substrates are shown in Fig. (6) indicating the formation of calcium phosphate structures. An SEM micrograph with specific points selected for elemental microanalysis is shown in Fig. (6), center panel. The results of elemental analysis of the selected points are presented in Table 2 .

Table 2. Results of EDS elemental analysis of HAp crystals on a $\mathrm{Ti6Al4V} / \mathrm{Al}_{2} \mathrm{O}_{3}$ substrate at selected points shown in Fig.6.

\begin{tabular}{|c|c|c|c|c|}
\hline Point & Al & Ca & P & Ca/P ratio, at. \% \\
\hline \hline 1 & 1.97 & 68.12 & 29.91 & 1.77 \\
\hline 2 & 2.31 & 66.16 & 31.53 & 1.62 \\
\hline 3 & 2.73 & 65.58 & 31.69 & 1.60 \\
\hline 4 & 2.34 & 66.68 & 30.98 & 1.67 \\
\hline
\end{tabular}

The EDS data show $\mathrm{Ca} / \mathrm{P}$ ratios close to those of stoichiometric hydroxyapatite. The calcium phosphate coatings deposited on Ti6Al4V substrates demonstrate a higher titanium content (Fig. 5) in comparison with HAp coatings on Ti6Al4 $/ / \mathrm{Al}_{2} \mathrm{O}_{3}$ substrates (Fig. 6).
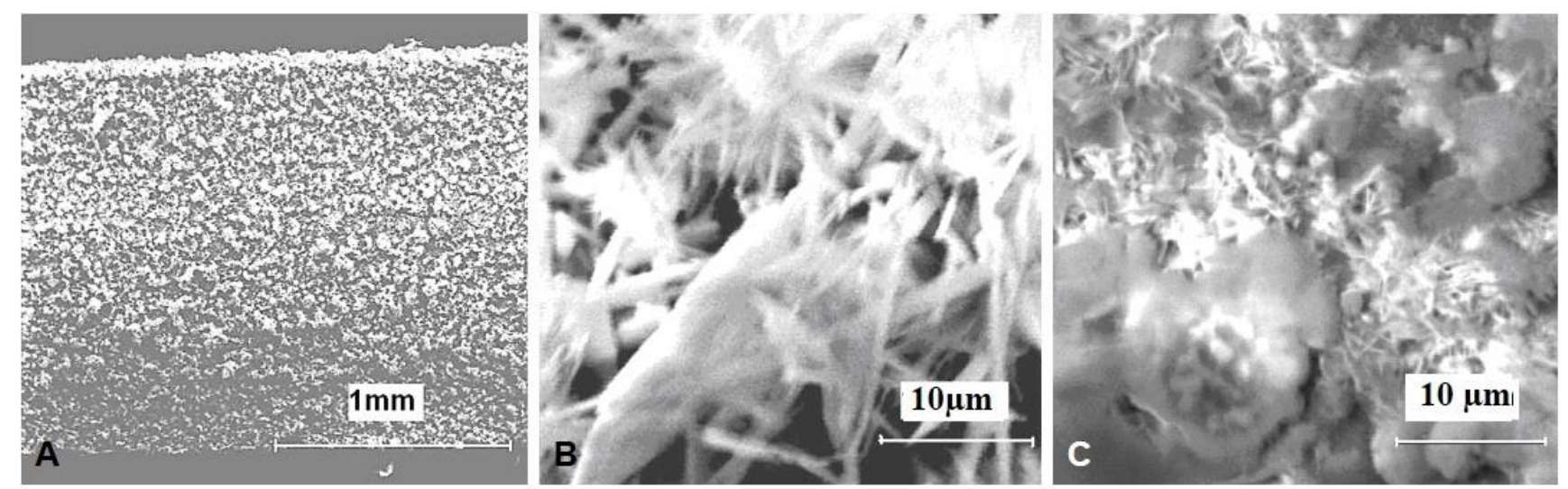

Fig. (4). SEM micrographs of calcium phosphate coatings deposited by the thermal method on a Ti6Al4Vsubstrate at different magnifications. 

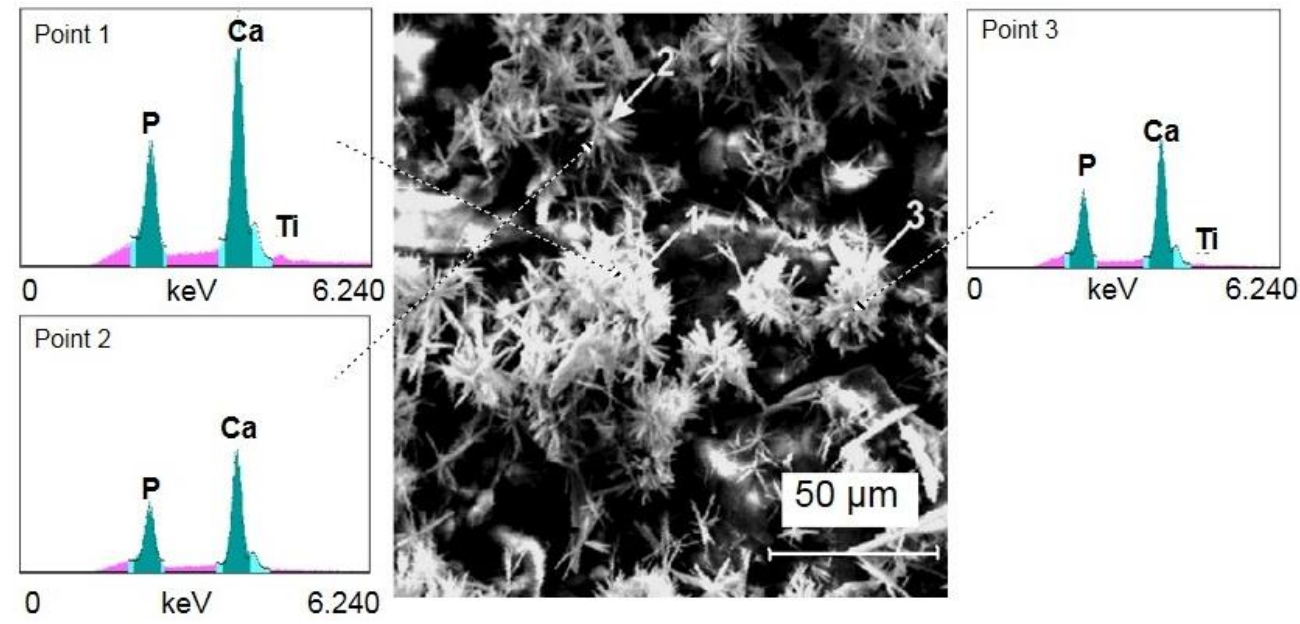

Fig. (5). EDS analyses data and SEM micrograph of the morphology of a calcium phosphate coatingdeposited by the thermal method on a Ti6Al4V substrate. Left and right panels: EDS analyses of selected points. Center panel: SEM micrograph with selected points indicated.
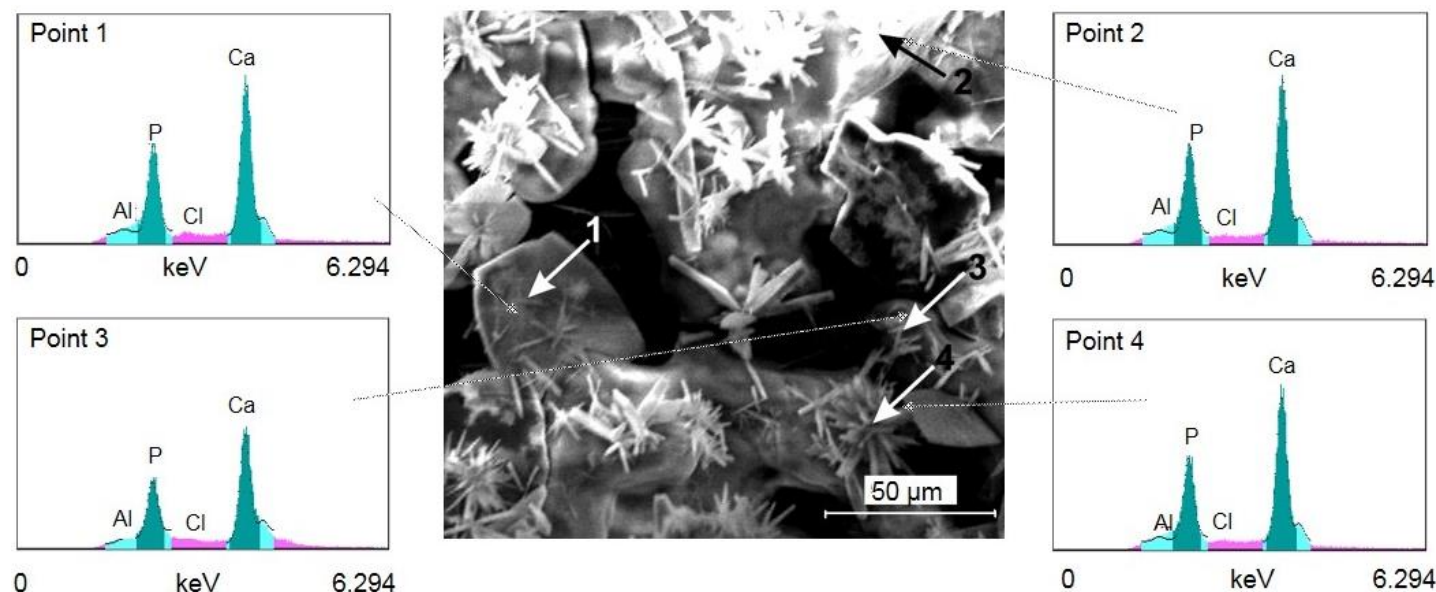

Fig. (6). EDS analysis data and SEM micrograph of the morphology of calcium phosphate coatingdeposited by the thermal method on a Ti6Al4V/ $/ \mathrm{Al}_{2} \mathrm{O}_{3}$ substrate.Left and right panels: EDS analyses of selected points. Center panel: SEM micrograph with selected points indicated.

Fig. (7) presents the corrosion tests of Ti6Al4V, Ti6Al4V/Al $\mathrm{O}_{3}$, Ti6Al4V/HAp and $\mathrm{Ti} 6 \mathrm{Al} 4 \mathrm{~V} / \mathrm{Al}_{2} \mathrm{O}_{3} / \mathrm{HAp}$ substrates in SBF solution. The ceramic oxide and the double-layered oxide-hydroxyapatite coatings demonstrate the highest corrosion potential compared with uncoated Ti6Al4V and single-layered Ti6Al4V/HAp substrates. The corrosion test results show that the oxide coating has significantly improved the corrosion resistance.

The mechanical characteristics of single-layer HAp coatings and double-layered ceramic aluminum oxide/ hydroxyapatite coatings deposited on Ti6Al4V substrates are presented in Table 3. The results demonstrate that corrosion resistance and mechanical parameters increase in the case of double-layered aluminum oxide /hydroxyapatite ceramic coatings.

The aluminum oxide-coated substrates show improved corrosion resistance compared to uncoated substrates. The surfaces with single-layer alumina and double-layered

Table 3. Mechanical characteristics of single-layer HAp coatings and double-layered alumina/hydroxyapatite coatings deposited onTi6Al4V substrates.

\begin{tabular}{|c|c|c|c|c|}
\hline Material/ coating types & Thickness $[\boldsymbol{\mu m}]$ & Adhesion strength $[\mathbf{N}]$ & Young's modulus $[\mathbf{G P a}]$ & Vickers hardness, HV $\left[\mathbf{k g f} / \mathbf{m m}{ }^{2}\right]$ \\
\hline \hline Ti6Al4V & & & $110 \pm 10$ & $415 \pm 20$ \\
\hline $\mathrm{Ti} 6 \mathrm{~A} 14 \mathrm{~V} / \mathrm{Al}_{2} \mathrm{O}_{3}$ & $2.1 \pm 0.2$ & $39.8 \pm 2$ & $172 \pm 15$ & $953 \pm 30$ \\
\hline $\mathrm{Ti} 6 \mathrm{Al} 4 \mathrm{~V} / \mathrm{HAp}$ & $30.3 \pm 0.5$ & $12.7 \pm 2$ & $102 \pm 10$ & $422 \pm 20$ \\
\hline Ti6Al4V $/ \mathrm{Al}_{2} \mathrm{O}_{3} / \mathrm{HAp}$ & $1.9 \pm 0.2 / 28.4 \pm 0.5$ & $35.2 \pm 2 / 8.9 \pm 2$ & $151 \pm 10$ & $831 \pm 30$ \\
\hline
\end{tabular}




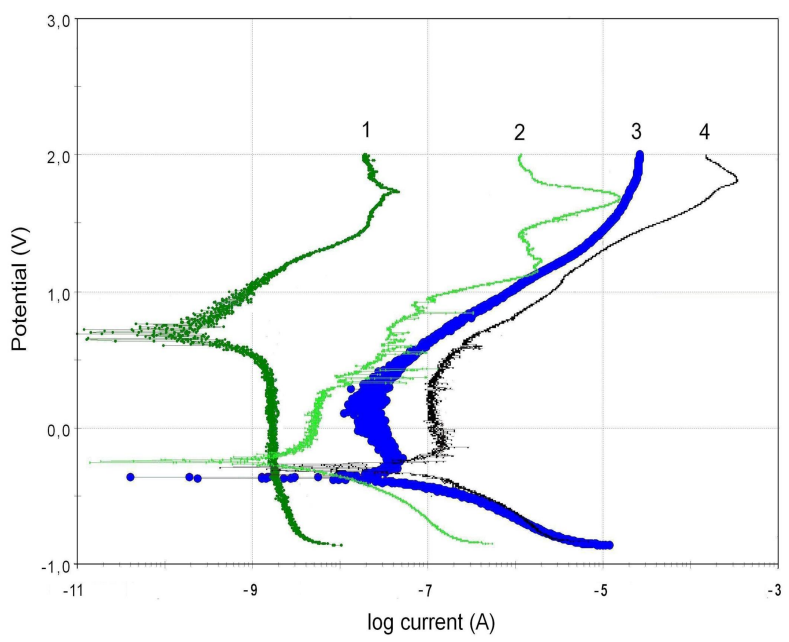

Fig. (7). Anodic polarization curves: 1- $\mathrm{Ti} 6 \mathrm{Al} 4 \mathrm{~V} / \mathrm{Al}_{2} \mathrm{O}_{3}, 2-$ Ti6Al4V/Al ${ }_{2} \mathrm{O}_{3} / \mathrm{HAp}$, 3- Ti6Al4V, 4- Ti6Al4V/HAp samples in SBF solution.

alumina/hydroxyapatite coatings have a strong capacitive response due to their electrically inert properties. The Vickers indentation hardness reaches maximum values up to $10 \mathrm{GPa}$ in the case of $\mathrm{Ti} 6 \mathrm{Al} 4 \mathrm{~V} / \mathrm{Al}_{2} \mathrm{O}_{3}$ and $\mathrm{Ti} 6 \mathrm{Al} 4 \mathrm{~V} / \mathrm{Al}_{2} \mathrm{O}_{3}$ /HAp coatings. The adhesion strength of HAp layers of comparable thickness was higher in the case of uncoated substrates (Table $\mathbf{3}$ ).

Cell cytotoxicity was estimated by in vitro tests. After 3 days immersion in DMEM culture medium fibroblast cells were well spread on all substrates. The cell structural organization corresponded to that of the initial fibroblast. After 5 days cultivation the density of cell increased for all samples. The majority of cells were ripe fibroblasts with strongly expressed phenotype, but meaningful differences in cell viability on substrate surfaces were not observed. However, a maximum number of detached cells were observed on uncoated titanium substrates after cultivation for 3 and 5 days (Fig. 8).

Cell morphology was observed by optical microscopy (Fig. 9). The cell profiles are well defined, with a great cytoplasm volume, large basophilic nuclei, hypochromic chromatin. Many cells are in different mitosis stages:

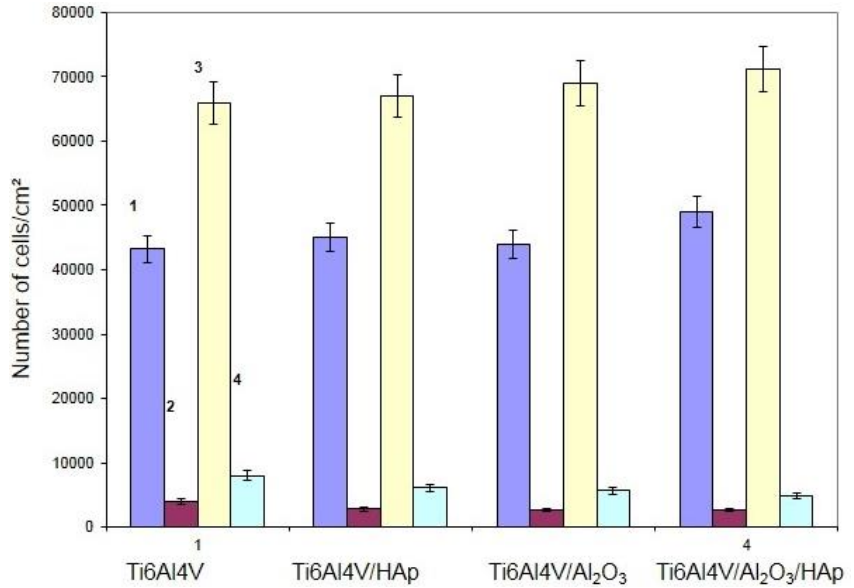

Fig. (8). Number of cells $/ \mathrm{cm}^{2}$ on the surface of Ti6Al4V substrates with single-and double-layered coatings: total cell number (1) and detached cell number (2) after 3 days cultivation, total cell number (3) and detached cell number (4) after 5 days cultivation; statistically significant differences were determined at a significance level $\mathrm{P}<0.05$.

prophase, metaphase, anaphase and telophase. Significant morphological differences in the cell structure, mitosis and destruction functions for samples Ti6 $\mathrm{Al} 4 \mathrm{~V} / \mathrm{Al}_{2} \mathrm{O}_{3}, \mathrm{Ti} 4 \mathrm{Al} 6 \mathrm{~V}$ $/ \mathrm{HAp}$ and $\mathrm{Ti} 6 \mathrm{Al} 4 \mathrm{~V} / \mathrm{Al}_{2} \mathrm{O}_{3} / \mathrm{HAp}$ in comparison with control ones were not observed. The distinction in the morphological structure of cell on the Ti6Al4V substrates was the formation of clusters of naked-nuclear cells. The presence of these cell types may be a signal of negative response of cell culture on the tested materials. The best biological response parameters (total cell number, viability and cell morphology) were obtained in the case of Ti6 $\mathrm{Al} 4 \mathrm{~V} / \mathrm{Al}_{2} \mathrm{O}_{3}$ and Ti6 $\mathrm{Al} 4 \mathrm{~V} / \mathrm{Al}_{2} \mathrm{O}_{3} /$ HAp substrates in comparison with uncoated Ti6Al4V substrates. The Ti6Al4V surfaces coated with a doublelayered aluminum oxide/hydroxyapatite coating demonstrate the best biocompatibility during in vitro tests.

\section{CONCLUSION}

A method was developed to deposit double-layered aluminum oxide/hydroxyapatite coatings by a hybrid technique involving magnetron sputtering and thermal deposition. The microhardness of aluminum oxide single-

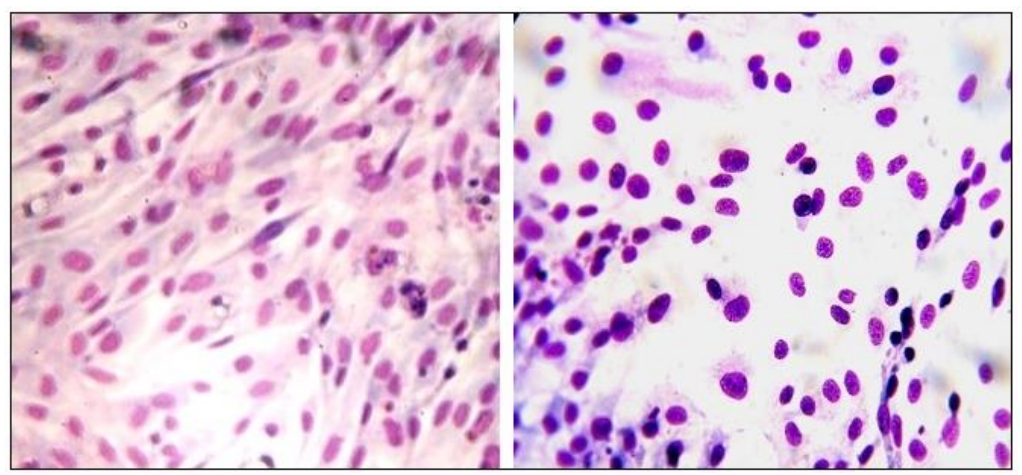

Fig. (9). Micrographs of fibroblastic cells on the surface after 5 days cultivation during in vitro tests. Left: double-layered alumina/calciumphosphate coating on a Ti6Al4V substrate. Right: area with separated cells and naked-nuclear cells on an uncoated Ti6Al4V substrate. Staining with hematoxylin and eosin, magnification $\times 400$. 
and double-layered coatings deposited on Ti6Al4V substrates increased significantly. The aluminum oxidecoated substrates demonstrated improved corrosion resistance compared to uncoated titanium substrates. The best corrosion resistance in SBF solutions was found for single-layered alumina-coated Ti6 $\mathrm{Al} 4 \mathrm{~V} / \mathrm{Al}_{2} \mathrm{O}_{3}$ and Ti6Al4V/ $/ \mathrm{Al}_{2} \mathrm{O}_{3} / \mathrm{HAp}$ double layer-coated materials. In conclusion, double-layered coatings with a calcium phosphate top layer over a protective aluminum oxide inner layer preventing ion diffusion were found to improve the mechanical properties as well as the biocompatibility during in vitro tests. Searching for new methods of surface modification and sputtering of inner layers with various chemical compositions should improve homogeneity and density of a calcium phosphate top layer formed by the thermal method.

\section{CONFLICT OF INTEREST}

The authors confirm that this article content has no conflict of interest.

\section{ACKNOWLEDGEMENTS}

Declared none.

\section{REFERENCES}

[1] T. Kokubo, H. M. Kim, and M. Kawashita, "Novel bioactive materials with different mechanical properties", Biomaterials, vol. 24, pp. 2161-2175, 2003.

[2] H. Liu, and T. J. Webster, "Nanomedicine for implants, "A review of studies and necessary experimental tools", Biomaterials, vol. 28, pp. 354-369, 2007.

[3] K. de Groot, R. Geesink, C. P. A. T. Klein, and P. Serekian, 'Plasma sprayed coatings of hydroxyapatite", Biomed. Mater. Res., vol. 21, pp. 1375-1381, 1987.

[4] R. B. Heimann, "Design of novel plasma-sprayed hydroxyapatitebond coat bioceramic systems", J. Thermal Spray Technol, vol. 8, no. 4, pp. 597-605, 1999.

[5] R. B. Heimann, "Recent trends towards improved plasma-sprayed advanced bioceramic coatings on Ti6Al4V implants", Materialwissenschaften und Werkstofftechnologie, vol. 30, pp. 775781, 1999.

[6] X. Liu, P. Chu, and C. X. Ding, "Surface modification of titanium, titanium alloys and related materials for biomedical application", Mater. Sci. Eng. Res., vol. 47, pp. 49-121, 2004.

[7] R. Gonzalez-McQuire, A. Tsetsekou, "Hydroxyapatite-biomelecule coating onto titanium surfaces", Surf. Coat. Technol., vol. 203, pp. 186-190, 2008.

[8] A. V. Zykova, S. V. Dudin, and K. I. Polozhiy, "Deposition of multilayer coatings for biomedical application by using of modern pulsed ion-plasma technology", In: Proc. APP Spring Meeting, Germany, pp. 95-98, 2003.

[9] H. M. Kim, F. Miyaji, T. Kokubo, and T. Nakamura, "Preparation of bioactive $\mathrm{Ti}$ and its alloys via simple chemical surface treatment", Biomed. Mater. Res., vol. 32, pp. 409-417, 1996.

[10] F. Li, O. I. Feng., F. Z. Cui, H. D. Li, and H. Schubert, "A simple biomimetic methods for calcium phosphate coating", Surf. Coat. Technol., vol. 154, pp. 88-93, 2002.

[11] D. Liu, K. Savino, and M. Z. Yates, "Coating of hydroxyapatite films on metal substrates by seeded hydrothermal deposition", Surf. Coat. Technol., vol. 205, pp. 3875-3986, 2011.

[12] L. B. Sukhodub, C. Moseke, L. F. Sukhodub, V. V. Pilipenko, and B. Sulkio-Cleff, "Improved thermal substrate method with cooling system for hydroxyapatite coatings on titanium substrates", Annual report 2002/2003 Institut für Kernphysik,Westfälische WilhelmsUniversität, Münster, pp. 86-88, 2003.

[13] K. Kuroda, R. Ichino, M. Okido, and O. Tokai, "Effect of ion concentration and $\mathrm{pH}$ on hydroxyapatite deposition from aqueous solution onto titanium by the thermal substrate method", Biomed. Mater. Res., vol. 61, pp. 354-359, 2002.

[14] K. Kuroda, R. Ichino, M. Okido, and O. Tokai, "Hydroxyapatite coating on titanium by thermal substrate method in aqueous solution", Biomed. Mater. Res., vol. 59, no. 2, pp. 390-397, 2002.

[15] M. Bohner, and J. Lemaitre, "Can bioactivity be tested in vitro with SBF solution?", Biomaterials, vol. 30, pp. 2175-2179, 2009.

[16] T. Kokubo, and H. Takadama, "How useful is SBF in predicting in vivo bone bioactivity", Biomaterials, vol. 27, pp. 2907-2915, 2006.

[17] S. W. Kweh, K. A. Khor, and P. Cheang, "An in vitro investigation of plasma-sprayed hydroxyapatite (HA) coatings produced with flame-spheroidized feedstock", Biomaterials, vol. 23, no. 3, pp. 775-785, 2002.

[18] I. Baltag, K. Watanabe, H. Kusakari, N. Taguchi, O. Miyakawa, M. Kobayashi, and N. Ito, "Long-term changes of hydroxyapatitecoated dental implants", J. Biomed. Mater. Res., vol. 53, pp. 1, pp. $76-85,2000$

[19] F. Fazan, and P. M. Marquis, "Dissolution behaviour of plasma sprayed hydroxyapatite coatings", Mater. Sci. Mater. Med., vol. 11, pp. 787-793, 2000 .

[20] E. Eisenbarth, D. Velten, K. Schenk-Meuser, P. Linez, V. Biehl, H. Duschner, J. Breme, and H. F. Hildebrand, "Interactions between Cells and Titanium Surfaces", J. Biomol. Eng., vol. 19, pp. 243249, 2002.

[21] Y. Okazaki, E. Gotoh, "Comparison of metal release from various metallic biomaterials in vitro", Biomaterials, vol. 26, no. 1, pp. 11$21,2005$.

[22] K. Merritt, and S. A. Brown, "Distribution of cobalt chromium wear and corrosion products and biologic reactions", Clin. Orthop. vol. 329 , pp. 233-243, 1996.

[23] A. A. Gudakova, S. N. Danilchenko, L. F. Sukhodub, V. V. Luk'yanchenko, A. V. Zykova, and V. I. Safonov, "The study of the oxide coating effect on bone-implant interface formation by means of electron microscopy method with energy dispersive X-ray analysis", Prob. At. Sci. Technol, vol. 13, pp. 145-147, 2007.

[24] R. M. Urban, J. J. Jacobs, M. J. Tomlinson, J. Gavrilovic, J. Black, and M. Peoc'h "Dissemination of wear particles to the liver, spleen and abdominal lymph nodes of patients with hip or knee replacement", J. Bone Joint Surg., vol. 82-A, pp. 457-476, 2000.

[25] A. V. Zykova, V. V. Luk'yanchenko, and V. I. Safonov, "The corrosion properties of implanted materials with protective properties in the isotonic physiological solution, Surf. Coat. Technol., vol. 200, pp. 90-93, 2005.

[26] T. Kokubo, T. Matsushita, and M. Takadema, "Titania-based bioactive materials", J. Eur. Ceram. Soc., vol. 27, pp. 1553-1558, 2007.

[27] X. Nie, A. Leyland, and A. Matthews, "Deposition of layered bioceramic hydroxyapatite/TiO2 coatings on titanium alloys using a hybrid technique of micro-arc oxidation and electrophoresis", Surf. Coat. Technol., vol. 125, pp. 407-414, 2000.

[28] H. Kurzweg, R. B. Heimann, T. Troczynski, and M. L. Wayman, "Development of plasma-sprayed bioceramic coatings with bond coats based on titania and zirconia", Biomaterials, vol. 19, pp. 1507-1515, 1998.

[29] D. H. Trinh, T. Kubart, T. Nyberg, M. Ottosson, I. Hultman, and H. Hogberg, "Direct current magnetron sputtering deposition of nanocomposite alumina-zirconia thin films", Thin Solid Films, vol. 516, pp. 8352-8358, 2008.

[30] G. Mendonça, D. B. Mendonça, L. G. Simões, A. L. Araújo, E. R. Leite, W. R. Duarte, F. J. Aragão, and L. F. Cooper, "The effect of implant surface nanoscale features on osteoblast-specific gene expression", Biomaterials, vol. 30, pp. 4053-4062, 2009.

[31] A. Zykova, V. Safonov, J. Smolik, R. Rogowska, V. Luk'yanchenko, O. Vyrva, and S. Yakovin, "The corrosion properties of zirconium and titanium load-bearing implant materials with protective oxide coatings", In: Proc. $13^{\text {th }}$ Int. Conf. PSE 2012, Linköping , Sweden, vol. 2, pp. 388-392, 2013.

[32] A. Zykova, V. Safonov, J. Walkowicz, R. Rogovska, and S. Yakovin, "The corrosion properties of multilayer coatings deposited on stainless steel and Ti4A16V substrates", Prob. At. Sci. Technol., vol. 15, pp. 156-158, 2009.

[33] M. Okido, K. Kuroda, M. Ishikawa, R. Ichino, and O. Takai, "Hydroxyapatite coating on titanium by means of thermal substrate method in aqueous solutions", Solid State Ionics, vol. 151, pp. 47$52,2002$. 
[34] A. Yanovska, V. Kuznetsov, A. Stanislavov, S. Danilchenko, and L. Sukhodub, "Synthesis and characterization of hydroxyapatitebased coatings for medical implants obtained on chemically modified Ti6Al4V substrates", Surf. Coat. Technol., vol. 205, pp. 5324-5329, 2011.

[35] V. Safonov, A. Zykova, J. Smolik, R. Rogowska, N. Donkov, A. Goltsev, T. Dubrava, I Rassokha and V Georgieva, "Nanoscale biomaterial interface modification for advanced tissue-engineering applications", J. Phys. Conf. Ser, vol. 356, pp. 012040, 2012.
[36] Q. Zhang, J. Chen, J. Feng, Y. Cao, C. Deng, and X. Zhang, "Dissolution and mineralization behaviors of HA coatings", Biomaterials, vol. 24, pp. 4741-4748, 2003.

[37] A. R. Boyd, B. J. Meenan, and N. S. Leyland, "Surface characterisation of the evolving nature of radio frequency (RF) magnetron sputter deposited calcium phosphate thin films after exposure to physiological solution", Surf. Coat. Technol., vol. 200, pp. 6002-6013, 2006.

Received: February 28, 2014

Revised: August 12, 2014

Accepted: August 14, 2014

(C) Zykova et al.; Licensee Bentham Open.

This is an open access article licensed under the terms of the Creative Commons Attribution Non-Commercial License (http://creativecommons.org/licenses/by-nc/3.0/) which permits unrestricted, non-commercial use, distribution and reproduction in any medium, provided the work is properly cited. 